Proceedings of the 10th International Ruminant Reproduction Symposium (IRRS 2018); Foz do Iguaçu, PR, Brazil, September 16th to 20th, 2018.

\title{
Impact of thermal stress on placental function and fetal physiology
}

\author{
Sean W. Limesand*, Leticia E. Camacho, Amy C. Kelly, Andrew T. Antolic
}

School of Animal and Comparative Biomedical Sciences, University of Arizona, Tucson AZ 85719 USA.

\begin{abstract}
In ruminants, prolonged exposure to high ambient temperatures negatively affects placental development and function. The pursuing limitations in placental oxygen and nutrient supply between the mother and fetus slow fetal growth lowering birth weights and postnatal performance. The pregnant ewe is a long-standing animal model for the study of maternalfetal interactions and is susceptible to naturally occurring heat stress, which causes fetal growth restriction. In the pregnant ewe, studies show that the fetus adapts to hyperthermia-induced placental insufficiency to preserve placental transport capacity of oxygen and nutrients. These adaptive responses are at the expense of normal fetal development and growth. Enlarged transplacental gradient for oxygen and glucose facilitates diffusion across the placenta, but develops by lowering fetal blood oxygen and glucose concentrations. Fetal hypoxemia and hypoglycemia slow growth and alter their metabolic and endocrine profiles. Deficits in amino acids transport across the placenta are present but are overcome by reduced fetal clearance rates, likely due to fetal hypoxemia or endocrine responses to hypoxic stress. Here, we provide an overview of the performance limitations observed in ruminants exposed to heat stress during pregnancy, but we focus our presentation on the sheep fetus in pregnancies complicated by hyperthermia-induced placental insufficiency. We define the characteristics of placental dysfunction observed in the fetus of heat stressed ewes during pregnancy and present developmental adaptations in organogenesis, metabolism, and endocrinology that are proposed to establish maladaptive situations reaching far beyond the perinatal period.
\end{abstract}

Keywords: heat stress, intrauterine growth restriction, placental insufficiency, sheep fetus.

\section{Introduction}

Environmental heat stress diminishes revenue for livestock producers by negatively impacting nutrient utilization, growth, and reproductive performance. Consequences of heat stress on early embryonic survival have been well documented, both scientifically and economically (Hansen et al., 2001). However, financial losses from warm environmental conditions are not limited to embryonic wastage. Maternal exposure to prolonged high ambient temperatures during gestation has been associated with lighter birth weights, greater incidence of morbidity before weaning, lower survival rates, and less desirable carcass traits (Shelton, 1964; Monteiro et al., 2016). As we will explain, these latter complications likely are products of developmental adaptations to nutrient and oxygen deprivation caused by hyperthermia-induced placental insufficiency. During maternal heat stress, fetal growth restriction may be considered beneficial for the dam, as a smaller conceptus yields less metabolically active tissue, greater maternal surface area to mass ratio, and less nutritional strain on the mother (Wells and Cole, 2002). Although fetal growth restriction is advantageous for the dam, fetal growth restriction and the accompanying adaptations to placental restriction are associated with a myriad of metabolic complications that negatively affect future performance.

Because offspring from a heat stressed dam are growth restricted during gestation, we begin with a closer look at the characteristics of placental dysfunction that restrict fetal growth and cause metabolic adaptations. We provide an overview of the performance limitations observed with maternal heat stress in ruminants, but focus our presentation on work conducted in sheep that are experimentally heat stressed during mid gestation, a time when the placenta is established and placental growth is at maximum (Regnault et al., 2002a). The pregnant sheep has been used extensively over the past 50 years to investigate placental and fetal physiology due to the ability to surgically place and maintain catheters in the maternal and fetal vasculature that allow for repetitive blood sampling from non-anesthetized ewes (Meschia et al., 1965; Barry et al., 2008). The substantial groundwork on maternal-fetal interactions in sheep provides ample knowledge for normal pregnancy, as well as information on models of pregnancies complicated by experimentally or naturally produced placental restriction, which includes a model of hyperthermiainduced placental insufficiency.

Pregnant ewes exposed chronically to high ambient temperatures in the laboratory from early to late gestation have fetuses that are significantly growth restricted close to term (Bell et al., 1987; Thureen et al., 1992). Ultrasonographic measurements indicate that biometric parameters for determining fetal growth restriction, for example abdominal circumference begins to diverge from normal as early as mid-gestation. This is a developmental point, prior to rapid fetal growth and at the apex of placental growth (Galan et al., 1999). Terminal studies indicate that significant reduction of placental mass precedes declines in fetal weight (Fig. $1 \mathrm{~A}$ and B). Before 110 days of gestation (term 149 days), placental weights were significantly less in heat stress ewes than controls $(280 \pm 32$ g vs. $443 \pm 32$ g). 
However, fetal weights were not affect at this younger age $(0.9 \pm 0.2 \mathrm{~kg}$ versus $1.0 \pm 0.2 \mathrm{~kg})$. After 130 days of gestation, both fetal and placental weights were significantly less in heat stressed ewes compared to controls (49\% for fetus and $56 \%$ for placenta). These data indicate that the majority of fetal growth restriction occurs during the final stages of gestation after placental growth restriction (de Vrijer et al., 2006; Macko et al., 2013). Limitations are caused by reduced placental mass and function, which leads to the development and progressive decline in fetal glucose (21 to 33\% less) and oxygen ( 25 to $46 \%$ ) concentrations over the final third of gestation, when fetal growth rate is at maximum (Limesand et al., 2013; Rozance et al., 2018; Fig. 1C and D). This evidence supports the hypothesis that placental deficiencies are responsible for fetal growth

A.

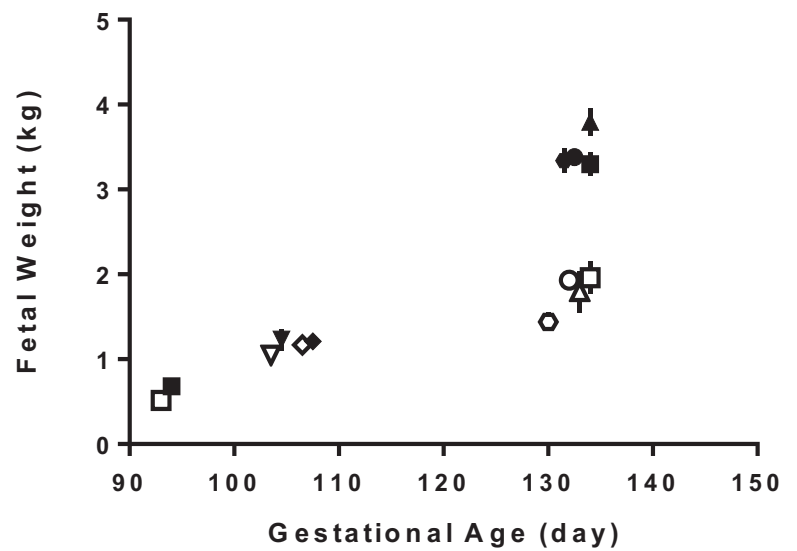

C.

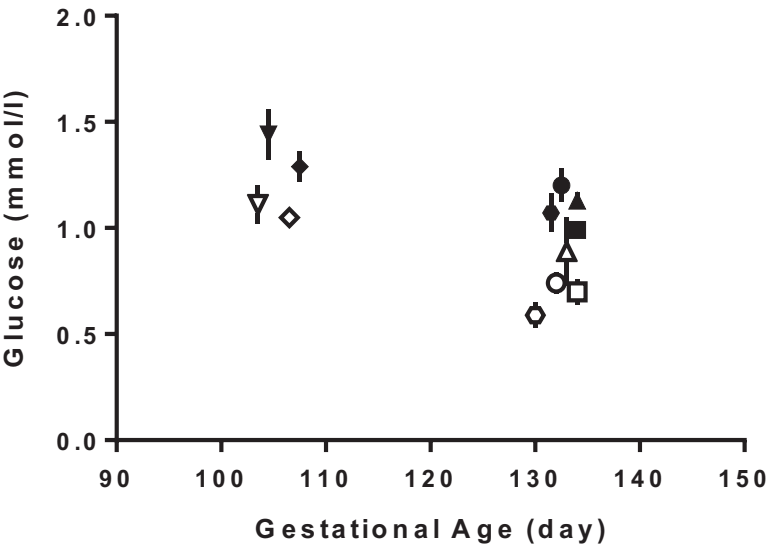

restriction in late gestation. Abnormal placental growth, vascular organization, and angiogenesis were described as possible causes of placental insufficiency due to aberrant expression patterns of angiogenic growth factors and their receptors (Vatnick et al., 1991; Regnault et al., 2002b; Galan et al., 2005; Hagen et al., 2005). Together, the pregnant ewe and this model of hyperthermia-induced placental insufficiency provides a unique opportunity to investigate fetal adaptive responses and growth restriction caused by a naturally induced placental restriction, which negatively effects their future health and performance. We review the outcomes in the placenta and fetus that are associated with adaptive responses to hyperthermia-induced placental insufficiency and discuss how they relate to future deficiencies in production.

B

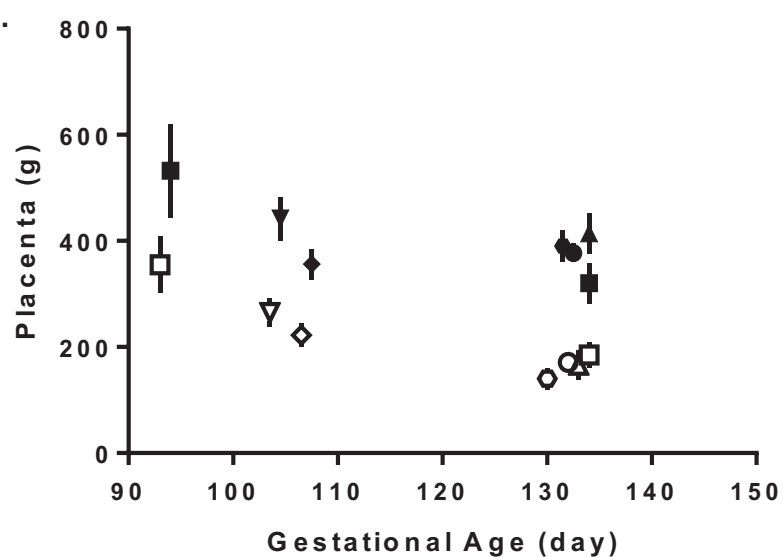

D

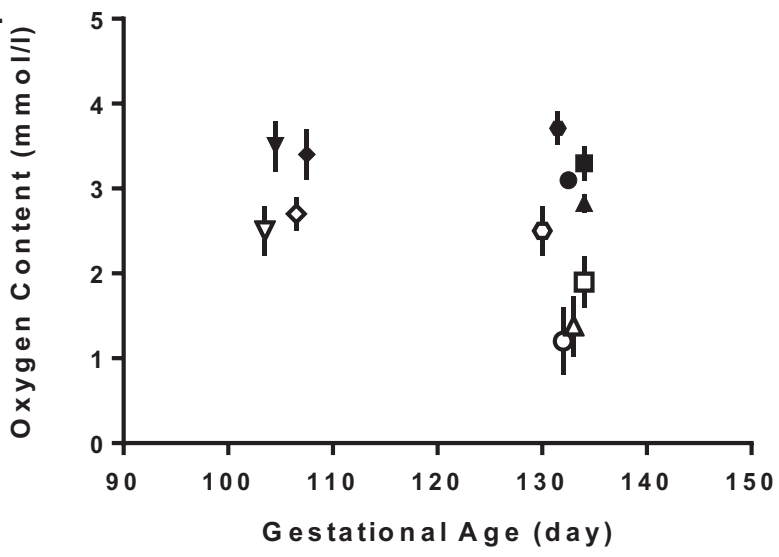

Figure 1. Progression of hyperthermia-induced placental insufficiency. Fetal weights (A), placental weights (B), fetal arterial plasma glucose concentrations (C), and fetal arterial blood oxygen contents (D) are presented as means reported in Ross et al., 1996 (hexagon); Brown et al., 2012 (circle); de Vrijer et al., 2006 (square <100 days); Limesand et al., 2013 (downward triangle), Macko et al., 2013 (diamond); and Rozance et al., 2018 (square >130 days). Each individual point represents a group mean for thermoneutral control ewes (fill shapes) and heat stress ewes (open shapes) for that specific report (symbol). At younger gestational ages ( $<110$ days), all group means were significantly different within a report, except for fetal weight. At older gestational ages ( $>130$ days), group means within the report were significantly different. Conclusions from these data indicate that advancing gestational age leads to greater differences in all parameters measured, which includes slower rates of fetal growth.

\section{Effects of heat stress in ruminants during gestation and lactation}

Environmental heat stress imposes significant limitations on fetal growth and milk production in several species of ruminants, but some species, usually those with higher production rates, are more susceptible to heat stress. For this reason, lactating dairy cows have a low tolerance to heat stress because as milk production per cow is increased there is a concurrent increase in metabolic heat production (Collier et al., 2006). Similarly, substantial economic consequences are incurred during gestation and lactation due to high metabolic heat output (West, 2003; Collier et al., 2006). 
Mechanisms that explain placental and fetal growth restriction include the redistribution of blood flow to the skin and nasal mucosa at the expense of other internal organs including the pregnant uterus (Reynolds et al., 1985; McCrabb et al., 1993). Reductions in placental function, along with maternal factors caused by heat stress, restrict mammary gland development and lower the potential yield for the subsequent lactation. In addition to losses in milk yield and quality following the immediate pregnancy, heat stress in late pregnancy effects immune processes associated with poor transition to lactation including: lower phagocytic activity and decreased hepatic prolactin signaling (PRL$\mathrm{R}$, SOCS-3, and CAV-1 mRNA) during the dry period (do Amaral et al., 2011). Milk yield and milk protein are influenced by calving season, as both are lowest during the warmest months compared to cows that calved in the winter (Barash et al., 2001). Lactating sheep are also susceptible to heat stress, which leads to differences in milk composition, specifically lower fat and protein content (Abdalla et al., 1993). In addition to lighter birth weights, calves from heat stress cows exhibited both immediate and prolonged effects on their passive immunity, growth, activity patterns, and thermotolerance (Ahmed et al., 2017; Laporta et al., 2017). Furthermore, the effects of heat stress on offspring persist, resulting in lower yearling weights and less heifers reaching their first lactation. Cows exposed to heat stress during fetal life produced less milk compared to cows that received heat abatement strategies (Monteiro et al., 2016). This evidence shows that heat stress during gestation affects fetal development and also creates lasting complications that lower the future productivity of the offspring, which may be caused by developmental adaptations to placental insufficiency.

\section{Maternal heat stress limits placental transport capacity}

The capacity of the placenta to transfer oxygen and nutrients must increase throughout pregnancy to meet metabolic demands of the growing fetus. In sheep, placental transport capacity continues to increase by expanding the surface area of the maternal-fetal interface and by thinning of the placental barrier to promote the exchange and permeability of metabolic substrates. Amino acids, oxygen, and glucose are transported across the placenta by active transport, passive diffusion, and facilitated diffusion (Battaglia and Meschia, 1978). For diffusion mechanisms, the rate of transplacental transport is dependent on uterine and umbilical blood flow, substrate permeability, and substrate concentration difference across the placenta.

Placental clearance is diminished with heat stress due to lower permeability for metabolic substrates. Oxygen and glucose permeability is reduced by a smaller placenta with less surface area and transport capacity, which combine to lower uterine extraction efficiency (Fig. 2). Evidence for this conclusion is that the transplacental gradients of oxygen and glucose increase in ewes exposed to environmental heat stress during pregnancy compared to pregnant ewes maintained under thermoneutral conditions (Fig. 3). Unlike placental transfer rates, placental clearance is independent of concentration gradients, but dependent on the properties of the exchanger (membrane) permeability or perfusion. Studies with inert molecules that have flow-limited placental transport show equivalent transplacental clearance rates in heat stressed and thermoneutral ewes. For example, there is no difference in ethanol clearance across the placenta between thermoneutral and heat stressed ewes when expressed relative to placental mass (Bell et al., 1987; Thureen et al., 1992; Regnault et al., 2007). This observation excludes shunting or uneven perfusion of uterine and umbilical blood flow as a cause for decreased transplacental clearance in heat stressed ewes. In addition to lower placental permeability, placental transport capacity of metabolic substrates is hindered by alterations in uteroplacental consumption of the substrate itself. In heat stressed ewes, uteroplacental oxygen consumption normalized to placental weight is unaffected, and glucose utilization by uteroplacental tissue is less (Bell et al., 1987; Thureen et al., 1992; Regnault et al., 2007). Therefore, the enlargement in the transplacental concentration difference for oxygen and glucose are due to lower placental permeability, which for glucose may be explained partially by lower abundance of facilitated glucose transporters (Limesand et al., 2004; Wallace et al., 2005).

Transplacental gradients and uterine-umbilical blood flow ratios adapt under heat stress to preserve the net umbilical uptake of glucose and oxygen, but as discussed later, this compensatory mechanism causes reductions in substrate concentrations in the fetus that become detrimental to development and growth (Bell et al., 1987; Thureen et al., 1992; Regnault et al., 2007, 2013). Simple concepts for diffusion indicate that larger transplacental concentration gradients (Fig. 3A and B) will increase the net movement of oxygen and glucose across the placenta to the fetus. Another compensatory mechanism is greater uterine-to-umbilical blood flow ratio, which further demonstrates impaired placental diffusion capacity in heat stressed ewes (Fig. 3C). Normally the uterine-to-umbilical blood flow ratio is $\sim 2$, which is predicted to fulfill the delivery requirements for the placenta and fetus because maximum fetal clearance occurs when flows are equivalent (Wilkening et al., 1982). Increases in the blood flow ratio lowers uterine arteriovenous differences for oxygen and aids in expanding the transplacental gradient to facilitate uterine uptake (Bell et al., 1987; Regnault et al., 2003). This adaptation may be advantageous to the fetus because it lowers cardiac output to the placenta to increase umbilical uptake, but the increase vascular resistance in the placenta is postulated to negatively affect the cardiovascular development (Galan et al., 2005). Together, the enlarged transplacental concentration gradients of oxygen and glucose and increased uterine-to-umbilical blood flow ratio are sufficient to minimize reductions in net umbilical oxygen and glucose uptake per fetal mass. However, comparisons for means across several 
reported cohorts indicate that there were modest but significant reductions of 9 and $14 \%$ in net umbilical oxygen and glucose uptakes, respectively (Fig. 4).

Placenta delivery of amino acids to the fetus is also lower in heat stressed ewes even though fetal plasma amino acid concentrations are not necessarily reduced (Thorn et al., 2009; Regnault et al., 2013). For most amino acids, concentrations in fetal circulation are normally greater than in maternal circulation and therefore are transported actively across the placenta against their concentration gradient. In heat stressed ewes, the absolute placental flux for essential amino acids from mother to fetus is reduced $\sim 80 \%$, whereas the flux relative to placental mass is $\sim 40 \%$ less (Ross et al., 1996; Anderson et al., 1997; de Vrijer et al., 2004). Similar reductions in transplacental uptake of essential amino acids are seen when expressed relative to fetal mass, with the exception of lysine (Regnault et al., 2013). Two important points become evident from these

A.

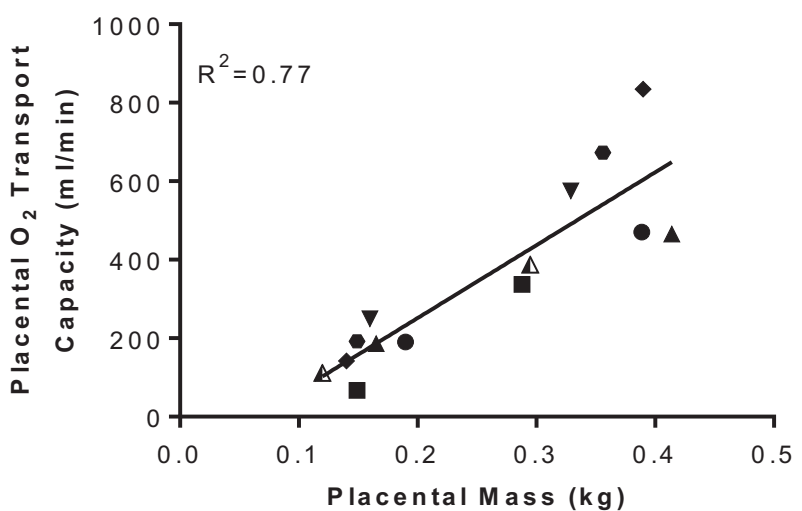

C.

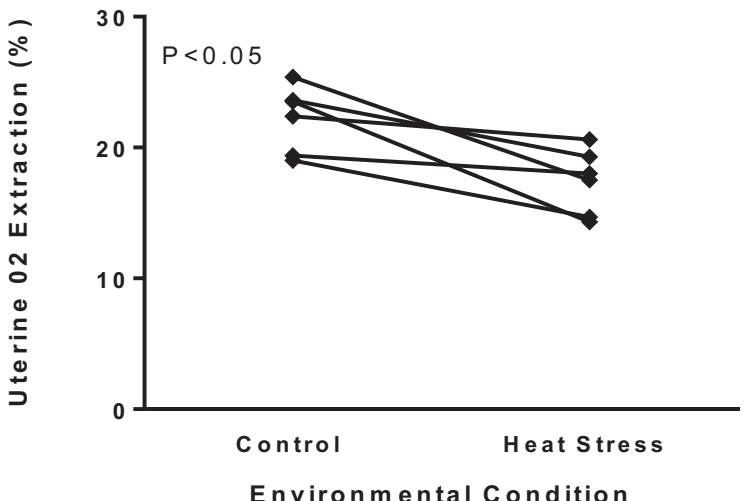

independent studies on amino acid placental transport in heat stress ewes. First, fetal uptakes of essential amino acids are reduced to similar magnitudes. Second, the impaired transport of amino acids is due to a reduction in placental size as well as decreased transport capacity per unit mass. Therefore, amino acid transfer depends on surface area of the maternal-fetal interface, which is reduced, as well as on the concentrations of amino acid transporters (Regnault et al., 2005). Interestingly, decreased transplacental flux of amino acid does not always lower their concentration in fetal plasma, implicating adaptive mechanisms in fetal metabolism or clearance of amino acids, which were associated with low oxygen concentrations (Regnault et al., 2013). Again, these data show that placental insufficiencies produced by heat stress depend on decreased placental mass and function, even though compensatory mechanism by the fetus are in place to assist with the placental deficiencies.

B

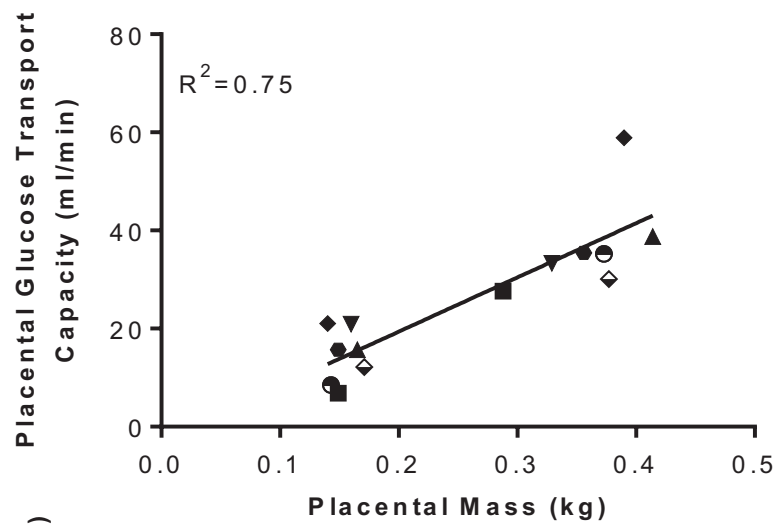

D.

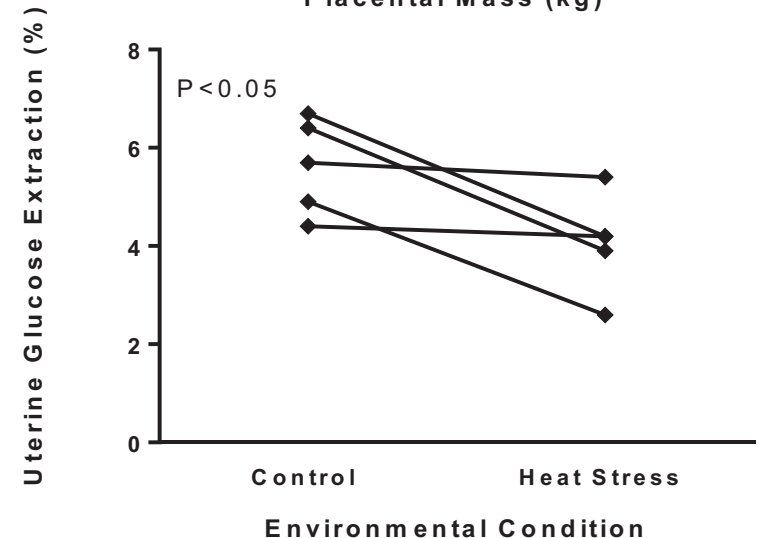

Figure 2. Placental transport capacity and uterine extraction efficiency for oxygen and glucose. Placental transport capacity for oxygen (A) and glucose (B) are presented by placental weights for independent group means from previously reported cohorts of thermoneutral and heat stressed ewes during gestation. Placental transport capacity is the net umbilical (fetal) uptake $(\mu \mathrm{mol} / \mathrm{min}$ ) divided by the maternal arterial-fetal arterial plasma concentration difference $(\mu \mathrm{mol} / \mathrm{ml})$ according to the equation: transport capacity $=$ uptake/concentration difference. Linear regression analysis shows a positive association for placental transport capacity and placental mass (R2). Uterine extraction of oxygen was calculated by expressing the whole blood arterial-venous oxygen concentration difference across the uterine circulation as a percent of the arterial concentration (C). Uterine extraction of glucose was expressed as the plasma arterial-venous concentration difference as a percent of the arterial glucose concentration (D). Group means for thermoneutral control (fill symbols) and heat stressed animals (open symbols) were reported in Bell et al., 1987 (downward triangle); Thureen et al., 1992 (hexagon); Ross et al., 1996 (diamond); Anderson et al., 1997 (small circle, panel A); Regnault et al., 2003 (large circle, panel A); Limesand et al., 2004 (circle, panel B); de Vrijer et al., 2004 (triangle); Limesand et al., 2007 (large square, panel B) and Brown et al., 2012 (small square, panel B). An ANOVA with reported study as the repeated measure identify group (control and heat stress) differences (P-values) for panels $\mathrm{C}$ and $\mathrm{D}$. 
A.

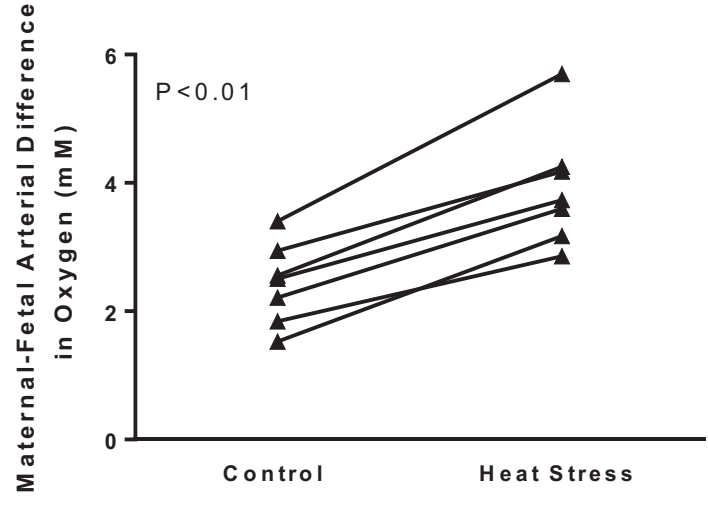

B .

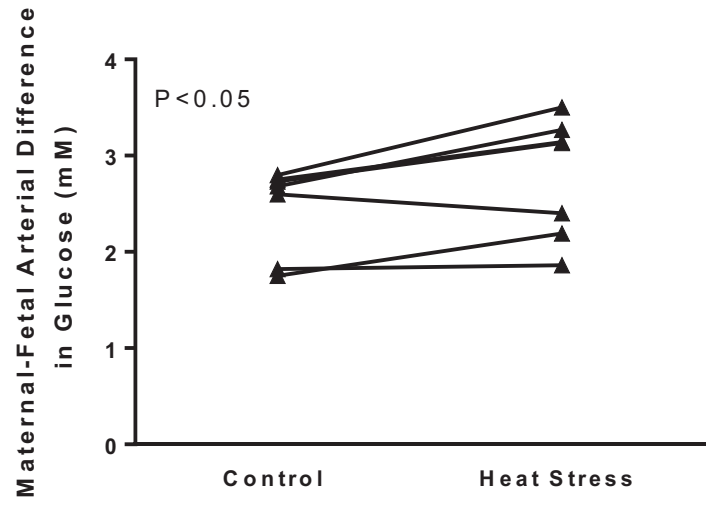

C.

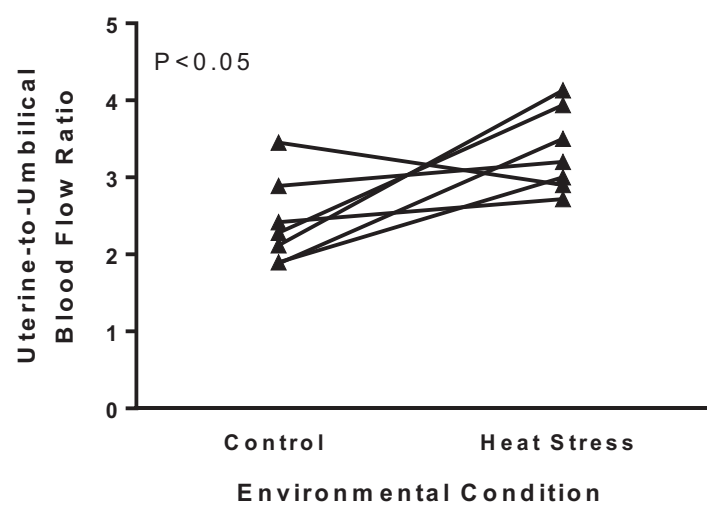

Figure 3. Transplacental gradients and uterine-umbilical blood flow ratio. Maternalfetal arterial difference for oxygen (A) and glucose (B) concentrations are presented for pregnant ewes at approximately $90 \%$ of gestation. Uterine-to-umbilical blood flow rates are presented in panel C. Group means for thermoneutral control and heat stressed ewes were reported in Bell et al., 1987; Thureen et al., 1992; Ross et al., 1996; Anderson et al., 1997; Regnault et al., 2003; Limesand et al., 2004, 2007; de Vrijer et al., 2004. An ANOVA with report as the repeated measure identifies group (control and heat stress) differences (P-values).

\section{Fetal responses to hyperthermia-induced placental insufficiency}

Maternal hyperthermia is natural in sheep that, uncharacteristically, carry pregnancies in summer months producing a smaller placenta with lower transport capacity for glucose, amino acids, and oxygen. Therefore, hyperthermia-induced placental insufficiency under-nourishes the fetus and leads to asymmetric intrauterine growth restriction (IUGR) that spares brain and heart growth relative to overall body weight (Fig. 5). In heat stressed sheep with placental insufficiency, we and others have characterized fetal adaptations in metabolism, endocrinology, and selected organ functions to specify mechanisms responsible for developmental programming. These studies have focused on fetal metabolism and endocrinology, pancreatic insulin secretion, hepatic glucose production, skeletal muscle growth and metabolism, and cardiac metabolism. In combination with oxygen and nutrient deficits, elevations in norepinephrine and epinephrine impinge on nearly all adaptive fetal responses measured including growth, glucose metabolism, and insulin secretion (Davis et al., 2015; Macko et al., 2016). How these fetal responses allow normal cellular oxidation to continue, maintain viability at the expense of growth, but ultimately become maladaptive for future performance are described herein.

\section{Fetal metabolism and endocrinology}

The fetus uses the umbilical uptake of nutrients to fulfill two major requirements: oxidation to fuel energy metabolism and accretion for growth and storage of substrates. Energy metabolism can be estimated from rates of oxygen consumption, which based on net umbilical oxygen uptake per fetal mass was only marginally less in IUGR fetuses compared to control 
fetuses (Fig. 4). For metabolic studies, the rate of oxygen consumption is one of the most useful standards of reference because the metabolic quotient defines the quantity of substrate needed to satisfy energy requirements of the fetus or fetal organs. This allows us to judge whether the quantity of nutrients being supplied to the fetus by the placenta is larger or smaller than the energy demands of the fetus, thus indicating whether the placental nutrient supply is sufficient to support fetal growth through accretion. The metabolic quotient for individual substrates are calculated as the ratio of the substrate oxygen equivalents to oxygen uptake. Oxygen equivalents are the quantity of oxygen molecules required for complete oxidation of that substrate to carbon dioxide and water. For example, when calculating the glucose/oxygen quotient, the glucose concentration difference $(\mathrm{mmol} / \mathrm{l})$ is multiplied by six and then divided by the oxygen concentration difference

A.

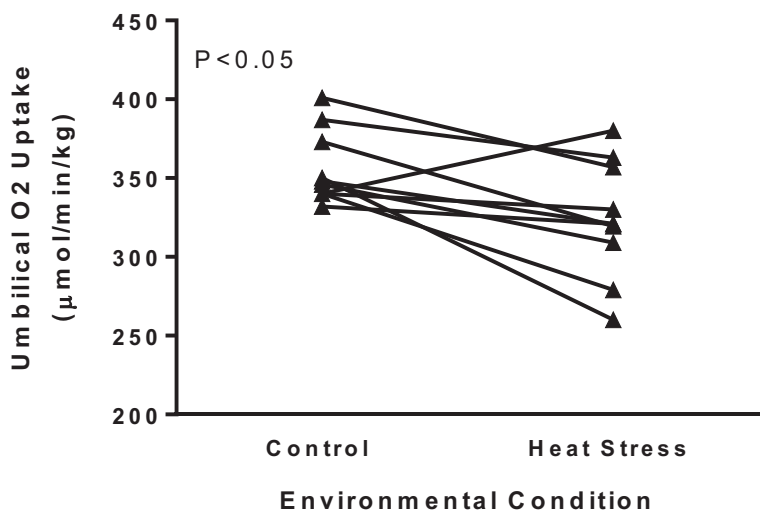

B

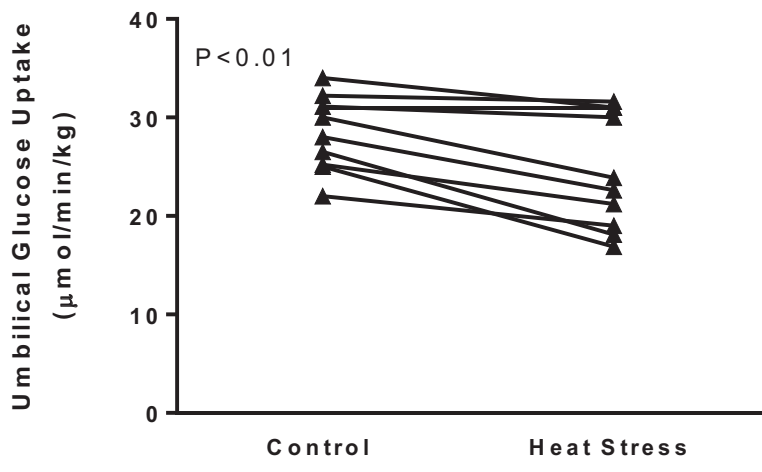

Environmental Condition

C.

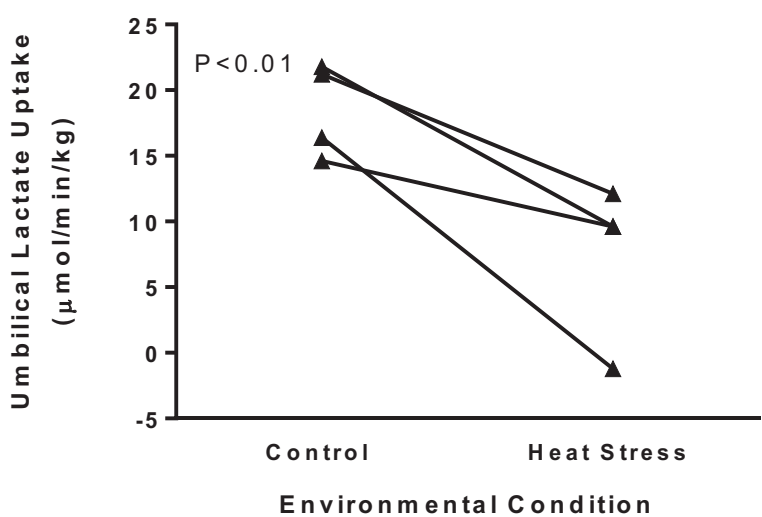

Although net umbilical (fetal) glucose uptakes were not significantly lower for all reports individually, the meta-analysis performed herein for ten reports that (mmol/l). In the fetus, the major sources for oxidative substrates are glucose, lactate, and amino acids, which explain the emphasis for studying their placental transport capacity and the resulting consequences to fetal growth when their delivery is restricted. Strikingly, the sum of the nutrient/oxygen quotients for glucose, lactate, and amino acids in IUGR fetus barely exceeds the umbilical oxygen quotient, which indicates that fetal uptake of nutrients is just sufficient to meet the oxidative requirements with no surplus for accretion (Regnault et al., 2013). A similar limitation in substrate availability was identified for the hindlimb quotients in IUGR fetuses (Rozance et al., 2018). Numerous studies have been conducted to explain how IUGR fetuses adapt to placental insufficiency by altering organ metabolism for these primary substrates as well as describing the potential endocrine regulation (Fig. 6).

Figure 4. Umbilical uptakes for oxygen, glucose, and lactate. Fetal weight-specific net umbilical uptakes for oxygen (A) and glucose (B) are presented for pregnant ewes at $90 \%$ of gestation. Group means for thermoneutral control and heat stressed ewes were reported in Bell et al., 1987; Thureen et al., 1992; Ross et al., 1996; Anderson et al., 1997; Regnault et al., 2003; Limesand et al., 2004, 2007; de Vrijer et al., 2004; Brown et al., 2012, 2015; and Thorn et al., 2013. An ANOVA with reported study as the repeated measure identifies group (control and heat stress) differences (P-values) for each of the uptakes.

measured umbilical glucose uptake show that glucose uptake was lower in IUGR fetuses (Fig. 4). Experiments with glucose tracers to determine rates of fetal glucose 
utilization and oxidation show significant alterations in glucose metabolism in IUGR fetuses with placental insufficiency (Limesand et al., 2007; Thorn et al., 2013; Brown et al., 2015). Body-weight specific glucose utilization rates are not different between IUGR and control fetuses, despite IUGR fetuses having markedly lower plasma insulin and glucose concentrations. In control fetuses, umbilical glucose uptake is normally equivalent to the glucose utilization rate, which demonstrates that placental glucose uptake is sufficient and glucose production is negligible. In IUGR fetuses with hyperthermia-induced placental insufficiency,

A

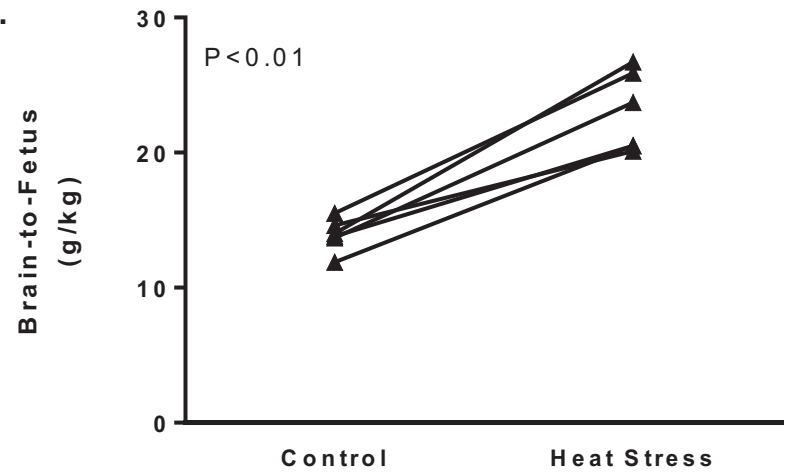

B.

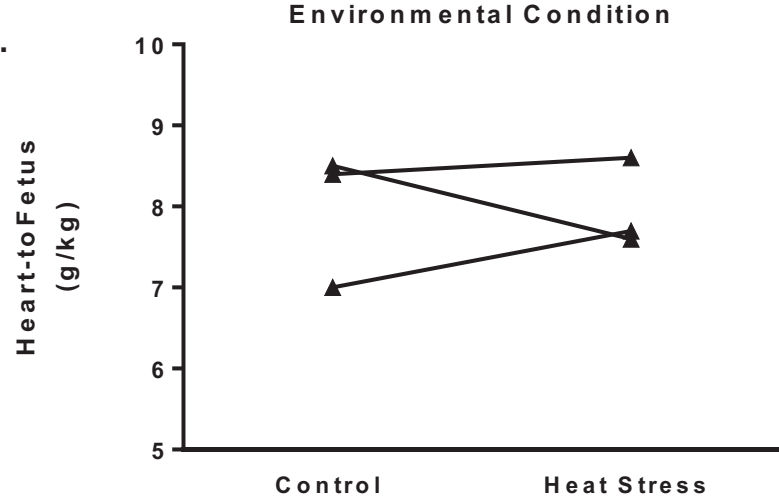

C.

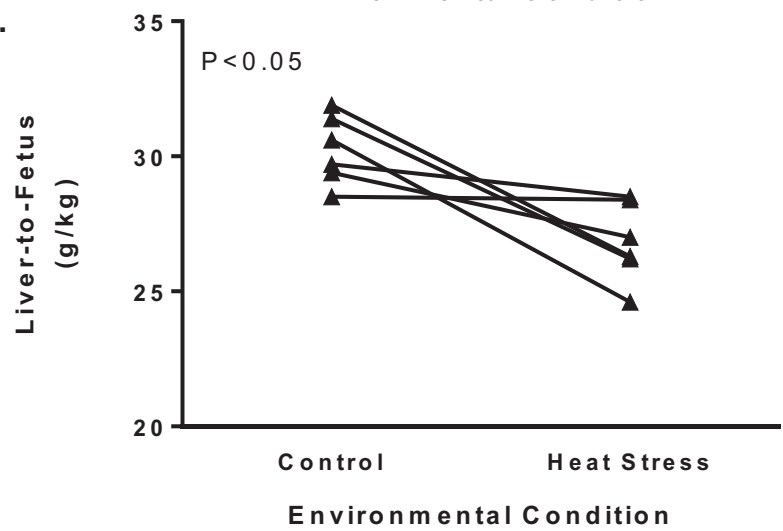

glucose utilization rates exceed umbilical glucose uptake, thus the IUGR fetus has endogenous glucose production (Limesand et al., 2007; Thorn et al., 2013). The fraction of glucose oxidized to carbon dioxide is also less in IUGR fetuses, which suggests peripheral tissues may have increased glycolysis to supply lactate for hepatic glucose production (Limesand et al., 2007; Brown et al., 2015). Together, these findings identify important metabolic responses in glucose metabolism that are predicted to caused alterations in tissues such as liver and muscle, changes in endocrine factors, or a combination of both
Figure 5. Asymmetric growth restriction with hyperthermia-induced placental insufficiency. Brain (A), heart (B), and liver (C) weights in grams are expressed relative to fetal weight $(\mathrm{kg})$ for fetuses necropsied at $90 \%$ of gestation. Group means for thermoneutral control and heat stressed ewes were reported in Thureen et al., 1992; Anderson et al., 1997; de Vrijer et al., 2004; Brown et al., 2012; Davis et al., 2015; and Barry et al., 2016. An ANOVA with reported study as the repeated measure identifies group (control and heat stress) differences (P-values) for organ to fetal weight ratios.
For glucose metabolism, three adaptations are apparent in IUGR fetuses with placental insufficiency. First, there is greater avidity for glucose uptake and utilization by fetal tissues in the presence of low glucose and insulin concentrations, indicating that there is greater insulin sensitivity in the IUGR fetus. Explanations for the greater glucose uptake capacity include a larger proportion of neuronal tissue to body weight (Fig. 5) and is supported by upregulation of glucose transporter 1 concentrations in the brain (Limesand et al., 2007). Furthermore, the glucose extraction efficiency and glucose uptake into both the hindlimb and myocardium are similar between control and IUGR fetuses, despite low glucose and insulin concentrations in the IUGR fetus (Barry et al., 2016; Rozance et al., 2018). Because glucose transporter expression was unaffected in IUGR muscle, adaptations in proximal insulin signaling were apparent and appear 
to enhance insulin sensitivity due to increased insulin receptor concentrations and decreased phosphoinositide3 kinase (p85) with no change in the p110 catalytic subunit (Limesand et al., 2007; Thorn et al., 2009). Second, IUGR fetuses exhibit hepatic glucose production, which is normally uncommon, but augmented by significant increases in gluconeogenic enzymes, PEPCK and glucose-6-phosphatase, perhaps in response to cAMP-response element-binding protein activation due to increases in cortisol, glucagon, and norepinephrine (Fig. 6; Limesand et al., 2007; Thorn et al., 2013). Third, enzymes that regulate the tricarboxylic acid cycle are altered in skeletal muscle and liver of IUGR fetuses. For example, pyruvate dehydrogenase kinase 4 mRNA expression is increased 5-fold in IUGR skeletal muscle. Pyruvate dehydrogenase kinase 4, when phosphorylated, inhibits pyruvate dehydrogenase, which

A.

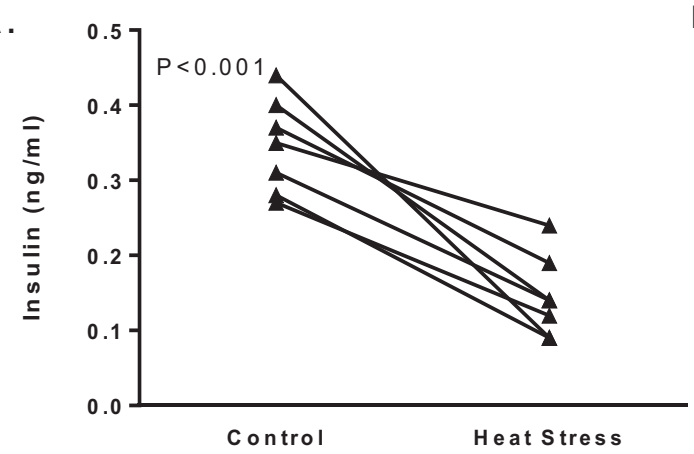

Environmental Condition

C.

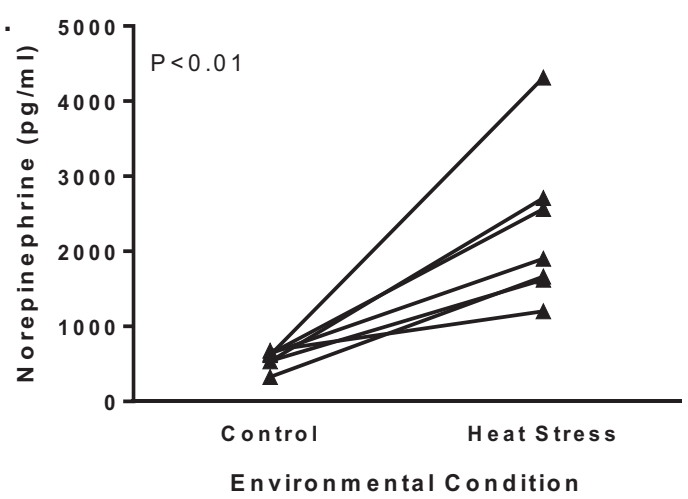

E .

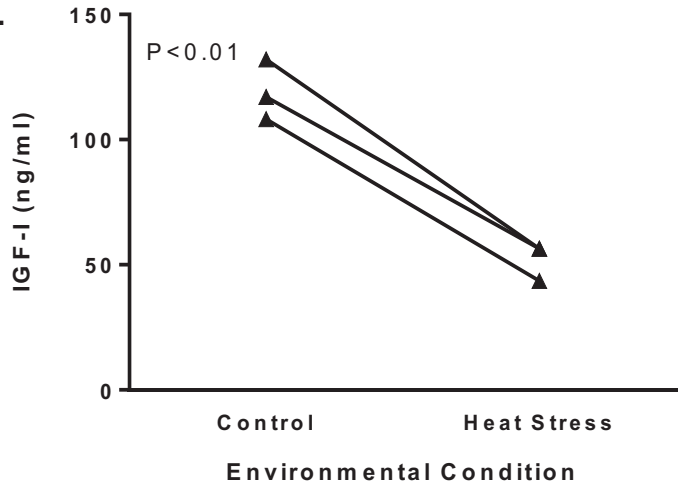

converts pyruvate to acetyl CoA for use in the tricarboxylic acid cycle (Brown et al., 2015). Pyruvate carboxylase and lactate dehydrogenases expression also were depressed in the skeletal muscle from IUGR fetuses, and the former may also play a role in sparing pyruvate via glycolysis from oxidative metabolism. Interestingly, lactate output from the hindlimb was not increased in IUGR fetuses. However, the lactate/oxygen quotient was greater, which shows greater lactate output per mole of oxygen consumed by the hindlimb of the IUGR fetus (Rozance et al., 2018). The sum of glucose and lactate quotient was similar between control and IUGR fetuses, and the amino acid/oxygen quotient was lower. This indicates that alterations in substrate utilization are more dependent on amino acid metabolism and protein synthesis and growth are expendable.

B .

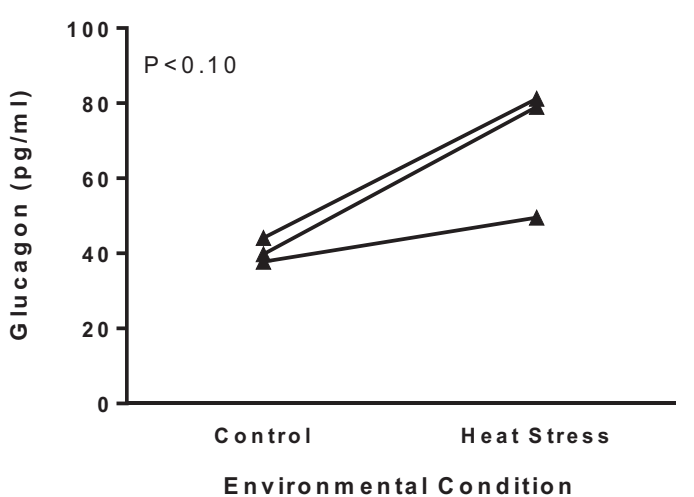

D .

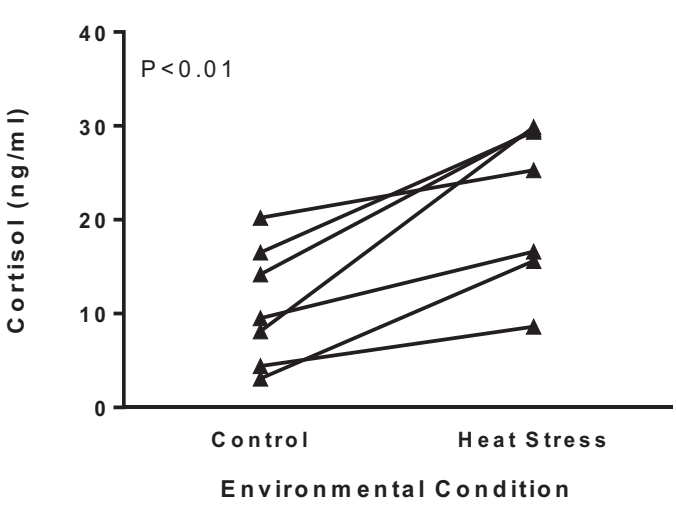

Figure 6. Endocrine profile in fetuses with hyperthermia-induced placental insufficiency. Mean plasma insulin (A), glucagon (B), norepinephrine (C), cortisol (D), and insulin-like growth factor I (IGF-I, E) concentrations are presented for fetuses at $90 \%$ of gestation. Group means for thermoneutral control and heat stressed ewes were reported in Limesand et al., 2006; Brown et al., 2012, 2016; Thorn et al., 2013; Macko et al., 2016; and Rozance et al., 2018. An ANOVA with reported study as the repeated measure identifies group (control and heat stress) differences (P-values) for hormone concentrations. 
We have followed IUGR lambs from heat stressed ewes and identified persistent augmentations in insulin sensitivity at least until two weeks of age (Camacho et al., 2017). These experiments demonstrate that in utero adaptations could have negative consequences during the postnatal growth period, and ultimately progress into insulin resistance because IUGR lambs with less muscle mass are adapting to their postnatal environment while also undergoing age related declines in insulin sensitivity (Gatford et al., 2004). Low birth weight and less muscle mass may cause metabolic limitation that decrease subsequent performance (Wu et al., 2006). As postnatal growth is largely dependent upon fetal growth and development, it is important to determine how management decisions could impact the growth trajectory of the fetus; however, it is not always feasible to prevent IUGR in production settings. Thus, identifying the mechanism that regulate skeletal muscle metabolism in IUGR during pre- and postnatal development is necessary.

\section{Pancreatic insulin secretion}

Pancreatic $\beta$-cells secrete insulin in response to elevated plasma glucose concentrations to stimulate glucose uptake into fetal tissues and promote growth. In fetal sheep, $\beta$-cells become responsive to glucose after mid-gestation (Aldoretta et al., 1998). Since insulin cannot cross the placenta, insulin secretion from fetal pancreatic $\beta$-cells is critical for coordinating fetal growth rates with the placental glucose transport. Insulin secretion parallels changes in glucose concentrations, and both glucose and insulin concentrations are lower in IUGR fetuses (Boehmer et al., 2017; Fig. 6). In IUGR fetuses, glucose concentrations are chronically low (Fig. 1), which negatively affects $\beta$-cell mass and insulin secretory capacity. The IUGR fetus has impaired insulin secretion responsiveness due to two primary deficits: less $\beta$-cell mass as a consequence of slower rates of $\beta$-cell proliferation and less insulin content per $\beta$-cell (Limesand et al., 2005, 2006).

Another factor contributing to the suppression of insulin secretion in IUGR fetuses is persistent elevations of plasma norepinephrine and epinephrine, which inhibit insulin secretion through $\alpha 2$-adrenergic receptors on $\beta$-cells (Jackson et al., 2000). In the IUGR fetus, glucose-stimulated insulin concentrations during an adrenergic receptor blockade are equivalent to maximal insulin concentrations in control fetuses (Leos et al., 2010; Macko et al., 2013). This response occurs despite IUGR fetuses having fewer $\beta$-cells that contain less insulin. Therefore, chronic adrenergic stimulation inhibits insulin secretion from fetal $\beta$-cells, but the chronic suppression in IUGR fetuses causes developmental changes in $\beta$-cells insulin secretion responsiveness. Following chronically high norepinephrine fetal infusions, a subsequent hypersecretory response of insulin has been confirmed in normally grown fetuses (Chen et al., 2014). Strikingly, in fetuses with a chronic norepinephrine infusion, the enhanced insulin secretion responsiveness to glucose and arginine persisted for five days after termination of the infusion. This is consistent with the observation of insulin hyper-secretion in week old IUGR lambs because norepinephrine concentrations are high during gestation but expected to decrease after birth when oxygen and nutrients are sufficient (Camacho et al., 2017; Chen et al., 2017; Limesand and Rozance, 2017). Surgical ablation of the fetal adrenal medulla prevents acute hypoxia-induced norepinephrine secretion and partially explains the lower glucose stimulated insulin concentrations in IUGR fetuses (Macko et al., 2016). While mechanisms for adrenergic inhibition of insulin secretion include distal steps in exocytosis, acute adrenergic stimulation also inhibits oxidative metabolism in $\beta$-cells and islets, which supports a role for norepinephrine to lower oxidation rates of glucose and to inhibit islet metabolism in IUGR fetuses (Kelly et al., 2018).

When islets from IUGR and control fetuses were analyzed for molecular changes using high throughput RNA sequencing (RNAseq), more than 1000 genes were differentially expressed and explained decreased cell proliferation (Kelly et al., 2017). This unbiased approach also revealed novel mechanisms underlying IUGR islet dysfunction including down regulation of immune function, suppressed Wnt signaling, adaptive stress responses, and impaired proteolysis. These transcriptional changes define adaptive responses of $\beta$-cells during IUGR and may provide the framework for understanding programming mechanisms that lead to metabolic complications in later life following hyperthermia-induced placental insufficiency.

\section{Skeletal muscle growth and metabolism}

Lambs with fetal growth restriction are lighter at birth and grow less efficiently, yielding carcasses with insufficient muscle growth (Greenwood et al., 1998, 2000). In sheep, the formation of new fibers (myogenesis) is complete around 110 days of gestation after which the myofibers grow by hypertrophy, which is when declines in fiber size are detected in fetuses with placental insufficiency-induced IUGR (Maier et al., 1992; Wilson et al., 1992; Hay et al., 2016). Conserved myonuclear domains during early muscle growth increase protein synthesis, such that myonuclear accumulation drives growth in young animals (Pavlath et al., 1989). Fetal myoblast incorporation (via differentiation) into myofibers is required to increase nuclei content because nuclei within these myofibers are post-mitotic (Allen et al., 1979). Myoblasts proliferate and differentiate in response to an activation signal, followed by a cascade of regulatory transcription factors (e.g. Pax7, MyoD, myogenin, and others). IUGR fetuses from hyperthermia-induced placental insufficiency have similar numbers of myoblasts compared to controls but have impaired myoblast differentiation due to slower rates of myoblast proliferation. (Yates et al., 2014, 2016; Brown et al., 2017). When myoblasts are isolated and cultured from IUGR skeletal muscle, they replicate slower than controls. This is likely an intrinsic defect in 
the IUGR myoblast because it occurs in culture and independent of nutrient availability (Yates et al., 2014). Furthermore, IUGR fetuses have decreased fiber size regardless of the fiber type (Yates et al., 2016). These complications explain smaller muscle fibers, as well as identify programing effects that could limit growth later in life (Brown, 2014).

Skeletal muscle is a primary target for metabolic complications because it represents approximately $40 \%$ of total body weight and greater than 50\% of energy expenditure (Brown, 2014). Metabolic energy requirements in skeletal muscle are met through oxidative phosphorylation. Thus, the number and efficiency of mitochondria determines metabolic capacity of muscle fibers. Traditionally, fibers are classified by oxidative capacity including Type Ia (slow oxidative), Type IIb (fast glycolytic), and Type IIa and IIx (fast oxidative; Dunlop et al., 2015). In the developing sheep the percentage of slow oxidative fibers (Type I) increases in number from less than $10 \%$ at 110 days gestation to greater than $25 \%$ near term and continues to increase postnatally (Maier et al., 1992). Myofiber area for both Type I and Type IIa fibers are decreased in hindlimb muscles from IUGR fetuses (Yates et al., 2016; Rozance et al., 2018). While there are less oxidative fibers in hindlimb muscles from IUGR fetuses, the proportion of glycolytic fibers is similar to control fetuses (Yates et al., 2016). We expect this developmental adaptation will lower oxidative-toglycolytic fiber ratios and explains impaired glucose oxidation rates in the IUGR fetus (Limesand et al., 2007; Brown et al., 2015).

Long-term exposure to elevated catecholamines down regulates adrenergic receptor concentrations, lowers sensitivity, and impairs skeletal muscle metabolism (Yates et al., 2014). Chronic adrenergic stimulation is associated with adaptive programming responses in fetal metabolic tissues: pancreatic islets (Chen et al., 2014; Camacho et al., 2017), skeletal muscle (Yates et al., 2012), and adipose (Chen et al., 2010). Moreover, adaptations to chronic adrenergic stimulation persist after the insult, creating the potential for life-long metabolic programming. Specifically, adrenergic receptor $\beta 2$ mRNA concentrations are reduced $>60 \%$ in IUGR fetuses and lambs but adrenergic receptors $\beta 1$ and $\beta 3$ are not different (Chen et al., 2010). Therefore, potential desensitization of adrenergic receptor $\beta 2$, but not other $\beta$-adrenergic receptors, might impair insulin responsiveness in skeletal muscle because it persists in lambs after birth.

\section{Cardiac metabolism}

The effects of maternal heat stress on fetal development and maturation are also evident in the heart. Blood flow to essential fetal organs (the brain, heart, and adrenal glands) is increased preferentially in response to acute bouts of hypoxia. As a result, blood flow decreases to the gastrointestinal, renal, and peripheral vasculature. This pattern for redistribution of cardiac output is also maintained during chronic periods of hypoxia such as those found in hyperthermia-induced placental insufficiency, which may result in the asymmetric fetal growth (Fig. 5).

IUGR fetal myocardium responds through unique metabolic and cardiovascular adaptations that support myocardial growth and function. The reduced circulating anabolic factors (Fig. 6) present in IUGR would be expected to suppress cardiac growth, as the fetal heart is sensitive to insulin and IGF-1, and reliant on glucose and lactate as major carbon sources for metabolism (Bartelds et al., 1998, 2000). The myocardium of the IUGR fetus responds by increasing plasma membrane concentrations of the insulinstimulated glucose transporter 4 and insulin receptor $\beta$ protein (Barry et al., 2006). In contrast, myocardial membrane protein concentrations of glucose transporter 1 are unchanged in the IUGR fetus. Additionally, blood flow to, and glucose delivery/uptake by, the left ventricle is significantly increased by insulin stimulation (Barry et al., 2016). These adaptations appear to promote myocardial energy supply and utilization by increasing its sensitivity to insulin, which supports cardiac growth despite the significant nutrient deprivation.

Fetal cardiac function appears to be relatively unaffected by placental insufficiency because heart rates are similar between IUGR and control fetuses (Galan et al., 2005; Barry et al., 2016). However, IUGR fetuses have increased indices of umbilical artery resistance and a significant reduction in umbilical blood flow, which did not always cause greater mean aortic blood pressure (Galan et al., 2005; Barry et al., 2016). The increased placental vascular resistance might reflect a mechanism by which the fetus is able to increase extraction of nutrients from the placenta as discussed above. A similar model that induces IUGR by removing the majority of the uterine caruncles in the sheep also found no difference in fetal blood pressure under baseline conditions; however, there was a greater hypotensive effect in IUGR fetuses following administration of phentolamine, an $\alpha$-adrenergic antagonist, and captopril, an angiotensin-converting enzyme inhibitor (Edwards et al., 1999; Danielson et al., 2005). These findings indicate that the $\alpha$-adrenergic and renin-angiotensin systems have a greater role in blood pressure maintenance in IUGR fetuses, which are likely involved in mediating some of the organ sparing phenomena present in this model (McMillen et al., 2001; Danielson et al., 2005).

\section{Conclusions}

We have presented evidence for prolonged exposure to heat stress causing placental insufficiency in ruminants. Maladaptive responses during development, which include fetal growth restriction, persist as lifelong deficiencies lowering the performance and health of the animal. We discuss how the enlarged transplacental gradient for oxygen and glucose facilitates umbilical uptakes but results in low blood oxygen and plasma glucose concentration in the fetus. These conditions slow growth by altering glucose metabolism, decreasing amino acid clearance, and decreasing anabolic hormones while increasing catabolic hormones. 


\section{Acknowledgements}

Funding for this work was from the National Institutes of Health R01 DK084842 (S.W. Limesand, Principal Investigator). L.E. Camacho was supported by Award 2015-03545 (L.E. Camacho, Principal Investigator) from the National Institute of Food and Agriculture, USDA. A.T. Antolic was supported by T32 HL7249 (J. Burt, Principal Investigator). We thank all our colleagues who contributed to the seminal studies reported in this review. The content is solely the responsibility of the authors and does not necessarily represent the official views of the funding agencies.

\section{References}

Abdalla EB, Kotby EA, Johnson HD. 1993. Physiological responses to heat-induced hyperthermia of pregnant and lactating ewes Small Rumin Res, 11:125-134.

Ahmed BMS, Younas U, Asar TO, Dikmen S Hansen PJ, Dahl GE. 2017. Cows exposed to heat stress during fetal life exhibit improved thermal tolerance. $J$ Anim Sci, 95:3497-3503.

Aldoretta PW, Carver TD, Hay WW Jr. 1998. Maturation of glucose-stimulated insulin secretion in fetal sheep. Biol Neonate, 73:375-386.

Allen RE, Merkel RA, Young RB. 1979. Cellular aspects of muscle growth: myogenic cell proliferation. $J$ Anim Sci, 49:115-127.

Anderson AH, Fennessey PV, Meschia G, Wilkening RB, Battaglia FC. 1997. Placental transport of threonine and its utilization in the normal and growthrestricted fetus. Am J Physiol, 272:E892-E900.

Barash H, Silanikove N, Shamay A, Ezra E. 2001. Interrelationships among ambient temperature, day length, and milk yield in dairy cows under a Mediterranean climate. J Dairy Sci, 84:2314-2320.

Barry JS, Davidsen ML, Limesand SW, Galan HL, Friedman JE, Regnault TR, Hay WW Jr. 2006. Developmental changes in ovine myocardial glucose transporters and insulin signaling following hyperthermia-induced intrauterine fetal growth restriction. Exp Biol Med (Maywood), 231:566-575.

Barry JS, Rozance PJ, Anthony RV. 2008. An animal model of placental insufficiency-induced intrauterine growth restriction. Semin Perinatol, 32:225-230.

Barry JS, Rozance PJ, Brown LD, Anthony RV, Thornburg KL, Hay WW Jr. 2016. Increased fetal myocardial sensitivity to insulin-stimulated glucose metabolism during ovine fetal growth restriction. Exp Biol Med (Maywood), 241:839-847.

Bartelds B, Gratama JW, Knoester H, Takens J, Smid GB, Aarnoudse JG, Heymans HS, Kuipers JR. 1998. Perinatal changes in myocardial supply and flux of fatty acids, carbohydrates, and ketone bodies in lambs. Am J Physiol, 4(6, pt. 2):H1962-1969.

Bartelds B, Knoester H, Smid GB, Takens J, Visser GH, Penninga L, van der Leij FR, Beaufort-Krol GC, Zijlstra WG, Heymans HS, Kuipers JR. 2000. Perinatal changes in myocardial metabolism in lambs. Circulation, 102:926-931.

Battaglia FC, Meschia G. 1978. Principal substrates of fetal metabolism. Physiol Rev, 58:499-527.

Bell AW, Wilkening RB, Meschia G. 1987. Some aspects of placental function in chronically heat-stressed ewes. J Dev Physiol, 9:17-29.

Boehmer BH, Limesand SW, Rozance PJ. 2017. The impact of IUGR on pancreatic islet development and beta-cell function. J Endocrinol, 235:R63-R76.

Brown LD, Rozance PJ, Thorn SR, Friedman JE, Hay WW Jr. 2012. Acute supplementation of amino acids increases net protein accretion in IUGR fetal sheep. Am J Physiol Endocrinol Metab, 303:E352-64.

Brown LD. 2014. Endocrine regulation of fetal skeletal muscle growth: impact on future metabolic health. $J$. Endocrinol, 221:R13-R29.

Brown LD, Rozance PJ, Bruce JL, Friedman JE, Hay WW Jr, Wesolowski SR. 2015. Limited capacity for glucose oxidation in fetal sheep with intrauterine growth restriction. Am J Physiol Regul Integr Comp Physiol, 309:R920-R928.

Brown LD, Davis M, Wai S, Wesolowski SR, Hay WW Jr, Limesand SW, Rozance PJ. 2016. Chronically Increased Amino Acids Improve Insulin Secretion, Pancreatic Vascularity, and Islet Size in Growth-Restricted Fetal Sheep. Endocrinology, 157:3788-3799.

Brown LD, Kohn, JR, Rozance PJ, Hay WW Jr, Wesolowski SR. 2017. Exogenous amino acids suppress glucose oxidation and potentiate hepatic glucose production in late gestation fetal sheep. Am $J$ Physiol Regul Integr Comp Physiol, 312:R654-R663.

Camacho LE, Chen X, Hay WW Jr, Limesand SW. 2017. Enhanced insulin secretion and insulin sensitivity in young lambs with placental insufficiency-induced intrauterine growth restriction. Am J Physiol Regul Integr Comp Physiol, 313:R101-R109.

Chen X, Fahy AL, Green AS, Anderson MJ, Rhoads RP, Limesand SW. 2010. beta2-Adrenergic receptor desensitization in perirenal adipose tissue in fetuses and lambs with placental insufficiency-induced intrauterine growth restriction. J Physiol, 588:3539-3549.

Chen X, Green AS, Macko AR, Yates DT, Kelly AC, Limesand SW. 2014. Enhanced insulin secretion responsiveness and islet adrenergic desensitization after chronic norepinephrine suppression is discontinued in fetal sheep. Am J Physiol Endocrinol Metab, 306:E58-E64.

Chen X, Kelly AC, Yates DT, Macko AR, Lynch RM, Limesand SW. 2017. Islet adaptations in fetal sheep persist following chronic exposure to high norepinephrine. J Endocrinol, 232:285-295.

Collier RJ, Dahl GE, VanBaale MJ. 2006. Major advances associated with environmental effects on dairy cattle. J Dairy Sci, 89:1244-1253.

Danielson L, McMillen IC, Dyer JL, Morrison JL. 2005. Restriction of placental growth results in greater hypotensive response to alpha-adrenergic blockade in fetal sheep during late gestation. J Physiol, 563:611-620.

Davis MA, Macko AR, Steyn LV, Anderson MJ, Limesand SW. 2015. Fetal adrenal demedullation lowers circulating norepinephrine and attenuates growth restriction but not reduction of endocrine cell mass in an ovine model of intrauterine growth restriction. Nutrients, 7:500-516.

de Vrijer B, Regnault TR, Wilkening RB, Meschia 
G, Battaglia FC. 2004. Placental uptake and transport of ACP, a neutral nonmetabolizable amino acid, in an ovine model of fetal growth restriction. Am J Physiol Endocrinol Metab, 287:E1114-1124

de Vrijer B, Davidsen ML, Wilkening RB, Anthony RV, Regnault TR. 2006. Altered placental and fetal expression of IGFs and IGF-binding proteins associated with intrauterine growth restriction in fetal sheep during early and mid-pregnancy. Pediatr Res, 60:507-512.

do Amaral BC, Connor EE, Tao S, Hayen MJ, Bubolz JW, Dahl GE. 2011. Heat stress abatement during the dry period influences metabolic gene expression and improves immune status in the transition period of dairy cows. J Dairy Sci, 94:86-96.

Dunlop K, Cedrone M, Staples JF, Regnault TR. 2015. Altered fetal skeletal muscle nutrient metabolism following an adverse in utero environment and the modulation of later life insulin sensitivity. Nutrients, 7:1202-1216.

Edwards LJ, Simonetta G, Owens JA, Robinson JS, McMillen IC. 1999. Restriction of placental and fetal growth in sheep alters fetal blood pressure responses to angiotensin II and captopril. J Physiol, 515:897-904.

Galan HL, Hussey MJ, Barbera A, Ferrazzi E, Chung M, Hobbins JC, Battaglia FC. 1999. Relationship of fetal growth to duration of heat stress in an ovine model of placental insufficiency. Am J Obstet Gynecol, 180:1278-1282.

Galan HL, Anthony RV, Rigano S, Parker TA, de Vrijer B, Ferrazzi E Wilkening RB, Regnault TR. 2005. Fetal hypertension and abnormal Doppler velocimetry in an ovine model of intrauterine growth restriction. Am J Obstet Gynecol, 192:272-279.

Gatford KL, De Blasio MJ, Thavaneswaran P, Robinson JS, McMillen IC, Owens JA. 2004. Postnatal ontogeny of glucose homeostasis and insulin action in sheep. Am J Physiol Endocrinol Metab, 286:E1050-E1059.

Greenwood PL, Hunt AS, Hermanson JW, Bell AW. 1998. Effects of birth weight and postnatal nutrition on neonatal sheep: I. Body growth and composition, and some aspects of energetic efficiency. J Anim Sci, 76:2354-2367.

Greenwood PL, Hunt AS, Hermanson JW, Bell AW 2000. Effects of birth weight and postnatal nutrition on neonatal sheep: II. Skeletal muscle growth and development. J Anim Sci, 78:50-61.

Hagen AS, Orbus RJ, Wilkening RB, Regnault TR, Anthony RV. 2005. Placental expression of angiopoietin-1, angiopoietin-2 and tie-2 during placental development in an ovine model of placental insufficiency-fetal growth restriction. Pediatr Res, 58:1228-1232.

Hansen PJ, Drost M, Rivera RM, Paula-Lopes FF, al-Katanani YM, Krininger CE, 3rd Chase CC Jr. 2001. Adverse impact of heat stress on embryo production: causes and strategies for mitigation. Theriogenology, 55:91-103.

Hay WW Jr, Brown LD, Rozance PJ, Wesolowski SR, Limesand SW. 2016. Challenges in Nourishing the IUGR fetus-lessons learned from studies in the IUGR fetal sheep. Acta Paediatr, 105:881-889.

Jackson BT, Piasecki GJ, Cohn HE, Cohen WR.
2000. Control of fetal insulin secretion. Am J Physiol Regul Integr Comp Physiol, 279:R2179-R2188.

Kelly AC, Bidwell CA, McCarthy FM, Taska DJ, Anderson MJ, Camacho LE, Limesand SW. 2017. RNA Sequencing exposes adaptive and immune responses to intrauterine growth restriction in fetal sheep islets. Endocrinology, 158:743-755.

Kelly AC, Camacho LE, Pendarvis K, Davenport HM, Steffens NR, Smith KE, Weber CS, Lynch RM, Papas KK, Limesand SW. 2018. Adrenergic receptor stimulation suppresses oxidative metabolism in isolated rat islets and Min6 cells. Mol Cell Endocrinol. doi: 10.1016/j.mce.2018.01.012

Laporta J, Fabris TF, Skibiel AL, Powell JL, Hayen MJ, Horvath K, Miller-Cushon EK, Dahl GE. 2017. In utero exposure to heat stress during late gestation has prolonged effects on the activity patterns and growth of dairy calves. J Dairy Sci, 100:2976-2984.

Leos RA, Anderson MJ, Chen X, Pugmire J, Anderson KA, Limesand SW. 2010. Chronic exposure to elevated norepinephrine suppresses insulin secretion in fetal sheep with placental insufficiency and intrauterine growth restriction. Am J Physiol Endocrinol Metab, 298:E770-E778.

Limesand SW, Regnault TR, Hay WW Jr. 2004. Characterization of glucose transporter 8 (GLUT8) in the ovine placenta of normal and growth restricted fetuses. Placenta 25, 70-77.

Limesand SW, Jensen J, Hutton JC, Hay WW Jr. 2005. Diminished b-cell replication contributes to reduced b-cell mass in fetal sheep with intrauterine growth restriction. Am J Physiol Regul Integr Comp Physiol, 288, R1297-R1305.

Limesand SW, Rozance PJ, Zerbe GO, Hutton JC, Hay WW Jr. 2006. Attenuated insulin release and storage in fetal sheep pancreatic islets with intrauterine growth restriction. Endocrinology, 147:1488-1497.

Limesand SW, Rozance PJ, Smith, D, Hay WW Jr. 2007. Increased insulin sensitivity and maintenance of glucose utilization rates in fetal sheep with placental insufficiency and intrauterine growth restriction. Am J Physiol Endocrinol Metab, 293:E1716-E1725.

Limesand SW, Rozance PJ, Macko AR, Anderson MJ, Kelly AC, Hay WW Jr. 2013. Reductions in insulin concentrations and beta-cell mass precede growth restriction in sheep fetuses with placental insufficiency. Am $J$ Physiol Endocrinol Metab, 304:E516-E523.

Limesand SW, Rozance PJ. 2017. Fetal adaptations in insulin secretion result from high catecholamines during placental insufficiency. $J$ Physiol 595, 5103-5113.

Macko AR, Yates DT, Chen X, Green AS, Kelly AC, Brown LD, Limesand SW. 2013. Elevated plasma norepinephrine inhibits insulin secretion, but adrenergic blockade reveals enhanced b-cell responsiveness in an ovine model of placental insufficiency at 0.7 of gestation. J Dev Orig Health Dis, 4:402-410.

Macko AR, Yates DT, Chen X, Shelton LA, Kelly AC, Davis MA, Camacho LE, Anderson MJ, Limesand SW. 2016. Adrenal demedullation and oxygen supplementation independently increase glucose- stimulated insulin concentrations in fetal sheep with intrauterine growth restriction. Endocrinology, 
157:2104-2115.

Maier A, McEwan JC, Dodds KG, Fischman DA, Fitzsimons RB, Harris AJ. 1992. Myosin heavy chain composition of single fibres and their origins and distribution in developing fascicles of sheep tibialis cranialis muscles. J Muscle Res Cell Motil, 13:551-572.

McCrabb GJ, McDonald BJ, Hennoste LM. 1993. Lamb birthweight in sheep differently acclimatized to a hot environment. Aust J Agric Res, 44:933-943.

McMillen IC, Adams MB, Ross JT, Coulter CL, Simonetta G, Owens JA, Robinson JS, Edwards LJ. 2001. Fetal growth restriction: adaptations and consequences. Reproduction, 122:195-204.

Meschia G, Cotter JR, Breathnach CS, Barron DH. 1965. The diffusibility of oxygen across the sheep placenta. QJ Exp Physiol Cogn Med Sci, 50:466-480.

Monteiro APA, Tao S, Thompson IMT, Dahl GE. 2016. In utero heat stress decreases calf survival and performance through the first lactation. J Dairy Sci, 99:8443-8450.

Pavlath GK, Rich K, Webster SG, Blau HM. 1989. Localization of muscle gene products in nuclear domains. Nature, 337:570-573.

Regnault TR, Galan HL, Parker TA, Anthony RV. 2002a. Placental development in normal and compromised pregnancies. Placenta, 23(suppl. A):S119-S129.

Regnault TR, Orbus RJ, de Vrijer B, Davidsen ML, Galan HL, Wilkening RB, Anthony RV. 2002b. Placental expression of VEGF, PlGF and their receptors in a model of placental insufficiency-intrauterine growth restriction (PI-IUGR). Placenta, 23:132-144.

Regnault TR, de Vrijer B, Galan HL, Davidsen ML, Trembler KA, Battaglia FC, Wilkening RB, Anthony RV. 2003. The relationship between transplacental O2 diffusion and placental expression of PlGF, VEGF and their receptors in a placental insufficiency model of fetal growth restriction. J Physiol, 550:641-656.

Regnault TR, Friedman JE, Wilkening RB, Anthony RV, Hay WW Jr. 2005. Fetoplacental transport and utilization of amino acids in IUGR--a review. Placenta, 26(suppl. A):S52-62.

Regnault TR, de Vrijer B, Galan HL, Wilkening RB, Battaglia FC, Meschia G. 2007. Development and mechanisms of fetal hypoxia in severe fetal growth restriction. Placenta, 28:714-723.

Regnault TR, de Vrijer B, Galan HL, Wilkening RB, Battaglia FC, Meschia G. 2013. Umbilical uptakes and transplacental concentration ratios of amino acids in severe fetal growth restriction. Pediatr Res, 73:602-611. Reynolds LP, Ferrell CL, Nienaber JA, Ford SP. 1985. Effects of chronic enviromental heat stress on blood flow and nutrient uptake of the gravid bovine uterus and foetus. J Agric Sci, 104:289-297.

Ross JC, Fennessey PV, Wilkening RB, Battaglia FC, Meschia G. 1996. Placental transport and fetal utilization of leucine in a model of fetal growth retardation. Am J Physiol, 270:E491-E503.

Rozance PJ, Zastoupil L, Wesolowski SR, Goldstrohm DA, Strahan B, Cree-Green M, Sheffield-Moore M, Meschia G, Hay WW Jr, Wilkening RB, Brown LD. 2018. Skeletal muscle protein accretion rates and hindlimb growth are reduced in late gestation intrauterine growth-restricted fetal sheep. J Physiol, 596:67-82.

Shelton M. 1964. Relation of birth weight to death losses and to certain productive characters of fall-born lambs. J Anim Sci, 23:355-359.

Thorn SR, Regnault TR, Brown LD, Rozance PJ, Keng J, Roper M, Wilkening RB, Hay WW Jr, Friedman JE. 2009. Intrauterine growth restriction increases fetal hepatic gluconeogenic capacity and reduces messenger ribonucleic acid translation initiation and nutrient sensing in fetal liver and skeletal muscle. Endocrinology, 150:3021-3030.

Thorn SR, Brown LD, Rozance PJ, Hay WW Jr, Friedman JE. 2013. Increased hepatic glucose production in fetal sheep with intrauterine growth restriction is not suppressed by insulin. Diabetes, 62:6573.

Thureen PJ, Trembler KA, Meschia G, Makowski EL, Wilkening RB. 1992. Placental glucose transport in heat-induced fetal growth retardation. Am J Physiol, 263:R578-R585.

Vatnick I, Ignotz G, McBride BW, Bell AW. 1991. Effect of heat stress on ovine placental growth in early pregnancy. J Dev Physiol, 16:163-166.

Wallace JM, Regnault TR, Limesand SW, Hay WW Jr, Anthony RV. 2005. Investigating the causes of low birth weight in contrasting ovine paradigms. $J$ Physiol, 565:19-26.

Wells JC, Cole TJ. 2002. Birth weight and environmental heat load: a between-population analysis. Am J Phys. Anthropol, 119:276-282.

West JW. 2003. Effects of heat-stress on production in dairy cattle. J Dairy Sci, 86:2131-2144.

Wilkening RB, Anderson S, Martensson L, Meschia G. 1982. Placental transfer as a function of uterine blood flow. Am J Physiol, 242:H429-H436.

Wilson SJ, McEwan JC, Sheard PW, Harris AJ. 1992. Early stages of myogenesis in a large mammal: formation of successive generations of myotubes in sheep tibialis cranialis muscle. J Muscle Res Cell Motil, 13:534-550.

Wu G, Bazer FW, Wallace JM, Spencer TE. 2006. Board-invited review: intrauterine growth retardation: implications for the animal sciences. J Anim Sci, 84:2316-2337.

Yates DT, Macko AR, Nearing M, Chen X, Rhoads RP, Limesand SW. 2012. Developmental programming in response to intrauterine growth restriction impairs myoblast function and skeletal muscle metabolism. $J$ Pregnancy, 2012:631038. doi: 10.1155/2012/631038.

Yates DT, Clarke DS, Macko AR, Anderson MJ, Shelton LA, Nearing M, Allen RE, Rhoads RP, Limesand SW. 2014. Myoblasts from intrauterine growth-restricted sheep fetuses exhibit intrinsic deficiencies in proliferation that contribute to smaller semitendinosus myofibres. J Physiol, 592:3113-3125.

Yates DT, Cadaret CN, Beede KA, Riley HE, Macko AR, Anderson MJ, Camacho LE, Limesand SW. 2016. Intrauterine growth-restricted sheep fetuses exhibit smaller hindlimb muscle fibers and lower proportions of insulin-sensitive Type I fibers near term. Am J Physiol Regul Integr Comp Physiol, 310:R1020R1029. 